\title{
Transient hypothyroxinaemia associated with developmental delay in very preterm infants
}

\author{
Wouter J Meijer, S Pauline Verloove-Vanhorick, Ronald Brand, J Leo van den Brande
}

\begin{abstract}
In 563 surviving very preterm ( $<32$ weeks gestational age) and/or very low birthweight $(<1500 \mathrm{~g})$ infants the relationship between neonatal thyroxine concentration and psychomotor development at 2 years of age (corrected for preterm birth) was studied. A significant association was found between low neonatal thyroxine concentration and a negative score on the three milestones of development. These findings do not support the view that transient hypothyroxinaemia in preterm infants is harmless.
\end{abstract}

Low thyroxine concentrations are very common in the first weeks of life in preterm and low birthweight infants. The thyroxine values are inversely related to gestational age and birth weight, ${ }^{1-3}$ and severity of respiratory and other neonatal disease. ${ }^{145}$ Such transient hypothyroxinaemia is viewed by many as an adaptive process. ${ }^{1245}$ However, its significance for later development has not been established for lack of large prospective studies, and the need for thyroid hormone replacement is controversial. ${ }^{6}$

We used the opportunity presented by a nationwide collaborative survey on very preterm and very low birthweight infants in The Netherlands to study the relationship between thyroxine values, as measured routinely in the national screening programme for congenital hypothyroidism, and later psychomotor development of the study infants as assessed in the follow up programme.

\section{Patients and methods}

The Project on Preterm and Small for Gestational Age Infants in The Netherlands is a collaborative survey collecting data on 1338 infants, liveborn in 1983 with a gestational age of less than 32 weeks and/or a birth weight of less than $1500 \mathrm{~g}^{78}$ The surviving infants all entered a standardised follow up programme up to 2 years of age, corrected for preterm birth. Examinations were performed by the local paediatricians, and the results were recorded on precoded forms designed to minimise the risk of interobserver variability. ${ }^{9} 10$

Psychomotor development was assessed at the corrected age of 2 years, using the Gesell test adapted for Dutch children (revised Van Wiechen test) after oral and written instruction following the standardised guidelines for this test. ${ }^{11} 12$ For the present study, the items obtained by history were omitted because of possible bias in reporting from the mother. The three developmental milestones chosen for analysis were obtained by direct observation of the child: 'builds tower of three blocks' (fine motor behaviour and coordination), 'walks without support' (gross motor function), and 'puts ball in box upon request' (passive language). Each of these milestones is reached at the age of 24 months by $90 \%$ of a group of normal children. ${ }^{11}$

These items were chosen as indicators of the effect of transient hypothyroxinaemia on development on theoretical grounds: the effect of a noxious influence on the developing nervous system depends on the postconceptional period in which the nervous system is exposed. ${ }^{13}$ The postconceptional period of transient hypothyroxinaemia in the study group resembles the period of prenatal hypothyroidism in early treated (before the age of 1 month) term born patients with congenital hypothyroidism. Prenatal hypothyroidism (retarded bone age, more marked hypothyroidism at birth) increases the risk of developmental delay at the age of 1.5 to 3 years - that is, a delay in psychomotor development which is not confined to one field of behaviour. ${ }^{14-18}$ Therefore, based on this analogy, the chosen measure of developmental delay in our study represents developmental delay which is not confined to one area of development: a developmental delay was assumed to be present when at least one of the three selected milestones was not reached.

Although the national screening programme for congenital hypothyroidism prescribes testing between days 6 and 8 , in practice only about $70 \%$ of all newborn infants are actually screened at that age; $97 \%$ are screened within 14 days from birth. ${ }^{19}$ In preterm infants, the delay in screening is greater.

Out of 944 children assessed at the corrected age of 2 years, screening values between days 5 and 17 could be obtained and linked to the follow up data in 563 cases (of which 479 (85\%) had been tested between days 6 and 11). Missing values were caused mainly by a later start in the collection of thyroxine values (midApril) compared with the perinatal data (1 January) and missing birth weight and gestational age in screening data, prohibiting linking $(n=311)$; missing thyroxine values because heel puncture was performed before day 5 or after day $17(n=56)$; by exclusion of disabling congenital malformations $(n=7)$, permanent primary congenital hypothyroidism $(n=1)$, and infants with temporary thyroid hormone replacement $(n=5)$; and unknown duration of ventilatory support $(n=1)$. Comparison of prenatal and perinatal characteristics showed no 
Table 1 Characteristics of the study group

\begin{tabular}{lcc}
\hline & $\begin{array}{l}\text { Study group } \\
(n=563)\end{array}$ & $\begin{array}{c}\text { Source } \\
\text { population* } \\
(n=953)\end{array}$ \\
\hline $\begin{array}{l}\text { Mean }(S D) \\
\text { Gestational age (weeks) }\end{array}$ & $31 \cdot 0(2 \cdot 6)$ & $31 \cdot 0(2 \cdot 5)$ \\
$\begin{array}{l}\text { Birth weight }(g) \\
\text { Highest bilirubin concentration ( } \mu \text { mol/l) }\end{array}$ & $1275(257)$ & $1315(283)$ \\
Average increase in body weight (g/day) & $176(43)$ & $178(45)$ \\
Number (\%) & $20 \cdot 1(4 \cdot 2)$ & $20 \cdot 2(4 \cdot 4)$ \\
Male & & \\
Small for gestational age & $280(49 \cdot 7)$ & $486(51 \cdot 0)$ \\
Apgar score $\geqslant 7$ & $288(40 \cdot 5)$ & $354(37 \cdot 1)$ \\
Respiratory distress syndrome & $471(83 \cdot 7)$ & $792(83 \cdot 1)$ \\
Intracranial haemorrhage and/or convulsions & $221(39 \cdot 3)$ & $371(38 \cdot 9)$ \\
Septicaemia & $97(17 \cdot 2)$ & $174(18 \cdot 3)$ \\
Duration of ventilatory support (days): & $171(30 \cdot 4)$ & $318(33 \cdot 4)$ \\
0 & $287(51 \cdot 0)$ & $490(51 \cdot 4)$ \\
$1-7$ & $163(29 \cdot 0)$ & $267(28 \cdot 0)$ \\
$8-28$ & $95(16 \cdot 9)$ & $165(17 \cdot 3)$ \\
$\geqslant 29$ & $18(3 \cdot 2)$ & $31(3 \cdot 3)$ \\
\hline
\end{tabular}

${ }^{*}$ Project on preterm and small for gestational age infants. ${ }^{7-10} 122+26$

important differences (table 1), and therefore we assume that no selection bias has occurred.

Thyroxine values were measured as part of the national screening for congenital hypothyroidism. ${ }^{20}$ In addition, a second measurement of thyroxine was performed on special request for the present study in 443 infants between 18 and 39 days of age. Thyroxine concentrations from filter paper eluates were determined in duplicate by radioimmunoassay ${ }^{21}$ in five laboratories with permanent laboratory quality control, ${ }^{22}$ each with an average of 125 samples per day. Thyroxine in the eluates was expressed as standard deviations about the mean calculated on a daily basis. ${ }^{23}$ When appropriate, thyroxine (T4) values have been calculated using a regression equation (T4 $(\mathrm{SD})=-4.065+0.0184 \times \mathrm{T} 4 \mathrm{nmol} / \mathrm{l})$, based on a correlation of simultaneously obtained blood spot thyroxine and serum thyroxine in 115 low birthweight infants on the seventh day of life, determined in the same laboratory. ${ }^{1}$

The relationship between thyroxine concentration and developmental outcome was studied using cross tabulations as well as multivariate stepwise logistic regression analysis with unconditional maximum likelihood estimation PROC LOGIST, Statistical Analysis System. Possible confounding factors were agreed before analysis, based on clinical experience and literature ${ }^{7-9}$ 24-26: infant's sex, gestational age, birth weight, weight for gestational age $(<10$ th centile), ${ }^{27} 28$ Apgar score at 5 minutes $(<7)$, age at thyroxine screening (in days), and highest observed neonatal serum bilirubin concentration $(\mu \mathrm{mol} / \mathrm{l})$. Covariables, related to neonatal disease, were: intracranial haemorrhage (clinical diagnosis based on rapid or saltatory deterioration, fall in erythrocyte sedimentation rate, and/ or ultrasound or computed tomography), ${ }^{24} 26$ seizures (irrespective of duration), respiratory distress syndrome (clinical diagnosis based on the need for extra oxygen for more than 24 hours, expiratory grunting, tachypnoea, sternal and intercostal retractions and nasal flaring, and/or typical radiograph), ${ }^{26}$ and sepsis (haematological findings of typical white cell count and/or positive blood culture). ${ }^{26}$

To control for severity of disease, two additional variables were included in the analysis: ventilatory support (total number of days of intermittent positive pressure ventilation or continuous positive airway pressure) which indicated the severity of respiratory disease, and the mean weight gain during hospital stay (g/day). Finally, a separate analysis was done in the subset of 228 infants in which grading of intracranial haemorrhage according to Papile ${ }^{29}$ was possible. ${ }^{24}$

The adjusted odds ratios are derived from logistist regression including all confounding factors listed above.

All statistical tests were two sided and a p value of less than 0.05 was considered to be significant.

\section{Results}

Mean thyroxine concentration in the 563 study infants was -2.4 (recalculated as $91 \mathrm{nmol} / \mathrm{l}$ ), which is considerably below the mean (SD) of the total screened population, which by definition is 0 (1 SD), or $221(54) \mathrm{nmol} / \mathrm{l}$. The range was $-5 \cdot 0$ to $+0.5 \mathrm{SD}$.

Psychomotor development, as assessed by the three items described, was normal in 473 (84\%) of the children, scoring all items positively. No relation was found between thyroxine and any of the three items separately. However, there was a significant association between thyroxine concentration and the number of children scoring negatively on at least one of the three items. Crude risks, odds ratios, as well as adjusted odds ratios, showed a linear increase of risk (table 2).

Assuming a linear relation, the overall crude odds ratio (not adjusted for potential confounding) for $1 \mathrm{SD}$ decrease in thyroxine was 1.4 $(p<0.01)$, implying a $40 \%$ increase in the odds that developmental delay will occur. After adjusting for the potential confounders, as mentioned in the patients and methods section, the odds ratio did not change appreciably, neither after adjusting for each covariable separately

Table 2 The association of thyroxine and psychomotor development $(n=563)$

\begin{tabular}{|c|c|c|c|c|c|c|c|c|c|c|}
\hline \multirow{3}{*}{$\begin{array}{l}\text { Thyroxine } \\
(S D)\end{array}$} & \multirow{3}{*}{$\begin{array}{l}\text { Calculated } \\
\text { thyroxine } \\
\text { (nmol/l) }\end{array}$} & \multicolumn{2}{|c|}{$\begin{array}{l}\text { Psychomotor } \\
\text { development }\end{array}$} & \multirow[t]{3}{*}{ Risk } & \multirow[t]{3}{*}{ Odds } & \multirow{3}{*}{$\begin{array}{l}\text { Crude } \\
\text { OR* }\end{array}$} & \multirow{3}{*}{$\begin{array}{l}\text { Crude } \\
\text { overall } \\
\text { OR }\end{array}$} & \multicolumn{3}{|c|}{$O R$ computed by regression analysis } \\
\hline & & & & & & & & Without & Adjustedt & Adjusted overall $O R$ \\
\hline & & Normal & Delay & & & & & adjusting & & by $I S D(95 \% C I)$ \\
\hline $\begin{array}{l}\geqslant-1 \cdot 0 \\
-1 \cdot 1 \text { to }-2 \cdot 0 \\
-2 \cdot 1 \text { to }-3 \cdot 0 \\
\leqslant-3 \cdot 1\end{array}$ & $\begin{array}{l}\geqslant 164 \\
110-163 \\
56-109 \\
\leqslant 55\end{array}$ & $\begin{array}{r}41 \\
121 \\
177 \\
134\end{array}$ & $\begin{array}{r}3 \\
15 \\
38 \\
34\end{array}$ & $\begin{array}{l}0 \cdot 07 \\
0 \cdot 11 \\
0 \cdot 18 \\
0 \cdot 20\end{array}$ & $\begin{array}{l}0.07 \\
0 \cdot 12 \\
0 \cdot 21 \\
0 \cdot 25\end{array}$ & $\begin{array}{l}\overline{1 \cdot 7} \\
2 \cdot 9 \\
3 \cdot 5\end{array}$ & $1 \cdot 4$ & $\begin{array}{l}\overline{1 \cdot 2} \\
2 \cdot 0 \\
3 \cdot 5\end{array}$ & $\left.\begin{array}{l}\overline{1.1} \\
1.9 \\
3.5\end{array}\right\}$ & $1 \cdot 4 \ddagger(1 \cdot 1$ to $1 \cdot 9)$ \\
\hline
\end{tabular}

OR, odds ratio.

'Relative to the group with thyroxine $\geqslant-1.0 \mathrm{SD}$; test for trend, $\mathrm{p}=0.003$.

tAdjusted for possible confounding factors, mentioned in the patients and methods section. $\neq p=0 \cdot 01$. 
nor after adjusting for all covariables simultaneously. The overall adjusted odds ratio was $1 \cdot 4$ $(95 \%$ CI $1 \cdot 1$ to $1 \cdot 9)$. In the subset of 228 infants with a known degree of intracranial haemorrhage, ${ }^{24}$ the crude adjusted odds ratios were the same as in the total study group; including the degree of intracranial haemorrhage in the analysis did not alter the odds ratio. Within the group of 90 children with developmental delay (at least one negative item), no relation was found between thyroxine concentration and number of negative items (Kruskall-Wallis one way analysis of variance $p>0.5)$.

\section{Discussion}

This study shows an association between thyroxine concentration and later psychomotor development in very preterm and very low birthweight infants who, having survived the first few days of life, took part in the national screening programme for congenital hypothyroidism. Even after adjusting for a number of obvious possible confounding factors representing degree of prematurity and severity of neonatal disease, a significantly increased risk of developmental delay was found in children with relatively lower neonatal thyroxine concentrations.

Preterm birth and severity of neonatal disease are known to be associated with both lower thyroxine values and poor developmental

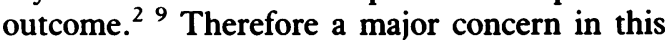
study was to preclude the possibility that the observed association between lower thyroxine and development delay was an artefact, with a common cause (preterm birth, neonatal disease). In our data, the overall odds ratio remained entirely unaffected after adjusting simultaneously for the carefully selected potential confounders, which virtually precludes the possibility of substantial residual confounding of this overall association. The 13 potential confounders which were included represent immaturity and neonatal disease. It is hardly imaginable that some fourteenth confounder would be able to cause any appreciable shift in the thyroxine developmental odds ratio after adjustment for 13 other confounders.

The systematic increase in the risk of developmental delay with decreasing thyroxine concentrations suggests the possibility of a causal relationship. The available literature on the essential function of thyroid hormones in growth and developmental of the nervous system $^{30-36}$ supports such a hypothesis. Thyroxine and triiodothyronine act on brain development and maturation by binding to triiodothyronine nuclear receptors. Serum thyroxine is the major source of brain triiodothyronine: approximately $70-80 \%$ of the triiodothyronine used by the cerebral cortex is produced in situ from thyroxine by a local 5' deiodinase. ${ }^{37-40}$ Thus, low serum thyroxine rather than low serum triiodothyronine indicates poor availability of thyroid hormones for the nervous system. In the animal model a deficiency of thyroid hormones leads to inhibition of cell differentiation and impaired myelination in a short critical age period. ${ }^{31}{ }^{33}$ In 33 very preterm ( $\leqslant 31$ weeks) and very low birthweight $(\leqslant 1500 \mathrm{~g})$ infants, prolonged hypothyroxinaemia was associated with a delay in progression in nerve conduction velocity, especially in those infants who also required ventilation. ${ }^{41}$ These results suggest that transient hypothyroxinaemia may interfere with neurological maturation. Furthermore, in our study group low thyroxine values were associated with a delay in psychomotor development not confined to one area of development; a similar type of delay was observed in early treated patients with congenital hypothyroidism. ${ }^{14-1618}$

As the duration of relevant hypothyroxinaemia may be important, the second measurement of thyroxine (between days 18 and 39, available in 443 infants) was included in an additional analysis. No association with outcome was observed, and neither was the observed association with early thyroxine concentrations changed. Possibly some compensatory mechanisms occur such as observed in the newborn hypothyroid rat $^{42}$ : an increased activity of 5 -deiodinase in the cerebral cortex, ${ }^{37}$ coincident with a reduction of the rate of degradation of triiodothyronine. ${ }^{39}$ These mechanisms act to keep the cerebrocortical content of triiodothyronine at euthyroid concentrations even when serum concentrations of thyroxine are severely reduced. ${ }^{39}$ The nervous system in newborn rats is comparable with the nervous system in humans in the third trimester of gestation and it has been suggested that in the hypothyroid human fetus these protective mechanisms may develop. ${ }^{42}$ As very preterm infants in the first weeks of life have a similar postconceptional age, the same protective mechanisms may develop in reaction to the reduced thyroxine levels. We are not aware of previous epidemiological studies in which the effect of transient hypothyroxinaemia was studied in a large population of very preterm or very low birthweight children. Lucas et al reported that low plasma triiodothyronine (lowest recorded concentration $<0.3 \mathrm{nmol} / \mathrm{l}$ ) in a cohort of 280 infants with birth weight below $1850 \mathrm{~g}$ was associated with the risk of developmental disadvantage at 18 months' corrected age. ${ }^{43}$ Because in the nervous system hypothyroidism is caused by low serum thyroxine rather than low serum triiodothyronine, ${ }^{37-40}$ the reported association of low serum triiodothyronine with delayed development may reflect the underlying effect of low serum thyroxine on the development of the nervous system.

In earlier studies ${ }^{44} 45$ such a delay was not observed. However, in one study ${ }^{43}$ where the number of infants was very small, thyroxine concentrations were measured in cord blood and development was assessed at a younger age. The thyroid hormone replacement trial ${ }^{45}$ compared only five treated children to three non-treated children at 12 months of age, and even fewer at 24 months. In such studies, the detection of a significant relationship is virtually impossible.

Although transient hypothyroxinaemia does not seem to be associated with gross damage, it may contribute to developmental delay. Our 
findings do not support the view that low thyroxine concentrations in preterm infants are harmless and that these infants do not require replacement treatment. The presumed undesirable effects of thyroid hormone supplementation on metabolism and oxygenation in the first weeks of life should be weighed against the possible benefits in terms of a more favourable developmental outcome at a later age.

We thank all paediatricians in The Netherlands for thei participation in this study: the heads of the phenylketonuria and congenital hypothyroidism screening laboratories, the Vaccination Administration Bodies and the Provincial Paediatricians for their enormous help, the National Steering Committees on Phenylketonuria and Congenital Hypothyroidism and the Chief Inspectorate for the State Supervision of Public Health (Dr H P Verbrugge) for giving their consent to this study, Dr J van Rijckevorsel for statistical advice, Dr E A Schlesinger-Was and P H Verkerk for advice and Mrs M Huls-van Vliet for secretarial assistance. The determinations of thyroxine in the second age period were performed by Dr W Schopman (Bergweg Hospital period were performed by Dr W Schopman (Bergweg Hospital,
Rotterdam). The data on the simultaneously determined Rotterdam). The data on the simultaneously determined thyroxine values in filter paper eluates and venous blood samples were provided by Dr J H Kok (neonatologist, Academic Medical Centre, Amsterdam). The data on development were provided by Dr D M van Zeben
Hospital, Leiden).

The study was supported by the Praeventiefonds, The Hague (grant 28-1143).

1 Kok JH, Hart G, Endert E, et al. Normal ranges of T4 screening values in low birthweight infants. Arch Dis Child 1983;58:190-4.

2 Kok JH. Thyroid function in preterm infants with and without the respiratory distress syndrome. Amsterdam: University of Amsterdam. Meppel: Krips Repro, 1985. (Thesis.)

3 Mercado M, Yu VY, Francis I, et al. Thyroid function in very preterm infants. Early Hum Dev 1988;16:131-41.

4 Burger AG, Davies R. Euthyroid low $T_{3}$ states. Pediatric and Adolescent Endocrinology 1985;14:327-44.

5 Delange F, Bourdoux P, Ermans AM. Transient disorders of thyroid function and regulation in preterm infants. Pedia tric and Adolescent Endocrinology 1985;14:369-93.

6 Smerdely P, Boyages SC, Wu D, et al. Topical iodinecontaining antiseptics and neonatal hypothyroidism in very-low-birthweight infants. Lancet 1989;ii:661-4.

7 Verloove-Vanhorick SP, Verwey RA, Brand R, et al. Neonatal mortality risk in relation to gestational age and birthweight. Results of a national survey of preterm and very-low-birthweight infants in the Netherlands. Lancet
1986;i:55-7.

8 Verloove-Vanhorick SP, Verwey RA. Project on preterm and small for gestational age infants in the Netherlands 1983 Leiden: State University. Ann Arbor, USA: University Microfilms International 8807276, 1987. (Thesis.)

9 Zeben van-Van der Aa DM, Verloove-Vanhorick SP,

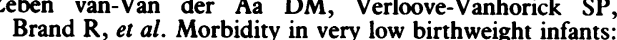
Brand $\mathrm{R}$, et al. Morbidity in very low birthweight infants: sequelae at the corrected age of 2 years in a geographically
defined population of very preterm and VLBW infants in defined population of very preterm and

10 Zeben van-Van der Aa DM. Outcome at 2 years of age in very preterm and very low birthweight infants in the Netherlands. Results from the nationwide collaborative follow-up study: project on preterm and small for gestational age infants, POPS, 1983. Leiden: State University, 1989. (Thesis.)

11 Schlesinger-Was EA. Longitudinal study of the psychomotor development of a group of infants in child health clinics. Tijdschrift Sociale Geneeskunde 1982;60:602-5.

12 Ouden den L, Rijken M, Brand R, et al. Is it correct to correct developmental milestones in 555 'normal' preterm infants compared with full term infants. $\mathcal{J}$ Pediatr 1991; 118:399-404.

13 Dobbing J, Smart JL. Vulnerability of the developing brain and behaviour. Br Med Bull 1974;30:164-8.

14 Glorieux J, Dussault JH, Morissette J, et al. Follow-up at ages 5 and 7 years on mental development in children with hypothyroidism detected by Quebec screening program. F Pediatr 1985;107:913-5.

15 Moschini L, Costa P, Marinelli E, et al. Longitudinal assessment of children with congenital hypothyroidism detected by neonatal screening. Helv Paediatr Acta 1986;41:415-24.

16 Rochiccioli P, Alexandre F, Roge B. Développement neurologique des hypothyroïdies néonatales. Arch Fr Pediatr 1987;44:721-4.
17 Fisher DA, Foley BL. Early treatment of congenital hypothyroidism. Pediatrics 1989;5:785-9.

18 Virtanen M, Santavuori P, Hirvonen E, et al. Multivariate analysis of psychomotor development in congenital hypothyroidism. Acta Paediatr Scand 1989;78:405-11.

19 Verkerk PH, Verloove-Vanhorick SP. Rapportage van de screening op congenitale hypothyreoidie bij kinderen geboren in 1990 . Verslag van de Landelijke Begeleidingscommissie CHT. Leiden: NIPG-TNO, 1991.

20 Meijer WJ. Screening op congenitale hypothyreoïdie. Tijdschr Kindergeneeskd 1985;53:92-8.

21 Chopra IJ. A radioimmunoassay for measurement of thyroxine in unextracted serum. F Clin Endocrinol Metab 1972;34:938-47.

22 Schopman W, Endert E, Kock de HW, et al. Analytische vergelijking van de CHT-laboratoria. Rapporten over het le t/m 4e kwartaal 1983. Bilthoven: National Institute of Public Health and Environmental Protection, 1983-1984.

23 Schopman W. Het L-thyroxine gehalte in ponsjes van bloedvlekken op PKU-CHT kaarten in de Nederlandse proefregio. Nucleair Geneesk Bulletin 1979;1:4-10.

24 Bor van de M, Verloove-Vanhorick SP, Baerts W, et al. Outcome of periventricular-intraventricular hemorrhage at 2 years of age in 484 very preterm infants admitted to 6 neonatal intensive care units in the Netherlands. Neuropediatrics 1988;19:183-5.

25 Bor van de $M$, Zeben van-Van der Aa DM, VerlooveVanhorick SP, et al. Hyperbilirubinemia in preterm infants and neurodevelopmental outcome at 2 years of age; results and neurodevelopmental outcome at 2 years of age; results of a natic

26 Verloove-Vanhorick SP, Zeben van-Van der Aa DM, Verwey $\mathrm{RA}$, et al. The male disadvantage in very-low-birthweightinfants: does it really exist? Eur $\mathcal{F}$ Pediatr 1989;149: 197-202.

27 Kloosterman GJ. Over Intra-uteriene groei en de intrauteriene groeicurve. Maandschrift voor Kindergeneeskunde 1969;37:209-25.

28 Kloosterman GJ. On intrauterine growth. The significance of prenatal care. Int f Gynaecol Obstet 1970;8:895-912.

29 Papile LA, Burstein J, Burstein R, et al. Incidence and evolution of subependymal and intraventricular hemorrhage: a study of infants with birthweights less than $1,500 \mathrm{gm}$. $\mathcal{F}$ Pediatr 1978;92:529-34.

30 Legrand J. Hormones thyroidiennes et maturation du Legrand $J$. Hormones thyroidiennes et maturation

31 Morreale de Escobar G, Ruiz Marcos A, Escobar del Rey F Thyroid hormone and the developing brain. In: Dussault $\mathrm{JH}$, Walker P, eds. Congenital hypothyroidism. New York: Marcel Dekker, Inc. Butterworths, 1983:85-126.

32 Fisher DA. Thyroid hormone effects on growth and develop ment. In: Delange F, Fisher DA, Malvaux $P$, eds. Pediatric thyroidology. Basel: Karger Press, 1985:75-89.

33 Dussault JH, Ruel J. Thyroid hormones and brain development. Ann Rev Physiol 1987;49:321-34.

34 Oppenheimer JH, Schwartz HL, Mariash $\mathrm{CN}$, et al. Advances in our understanding of thyroid hormone action at the cellular level. Endocr Rev 1987;8:288-308.

35 Timiras PS, Nzekwe EU. Thyroid hormones and nervous system development. Biol Neonate 1989;55:376-85.

36 Bongers-Schokking JJ, Colon EJ, Hoogland RA, et al. Somatosensory evoked potentials in neonates with primary congenital hypothyroidism during the first week of congenital hypothyroidism during

37 Larsen PR, Silva JE, Kaplan MM. Relationships between circulating and intracellular thyroid hormones: physiology and clinical implications. Endocr Rev 1981;2:87-102.

38 Crantz FR, Silva JE, Larsen PR. An analysis of the sources and quantity of $3,5,3^{\prime}$-triiodothyronine specifically bound to nuclear receptor in rat cerebral cortex and cerebellum Endocrinology 1982;110:367-75.

39 Silva JE, Larsen PR. Comparison of iodothyronine 5' deiodinase and other thyroid-hormone-dependent enzyme activities in the cerebral cortex of hypothyroid neonatal rat f Clin Invest 1982;70:1110-23.

40 Morreale de Escobar G, Obregon MJ, Ruiz de Oña C, et al. Transfer of thyroxine from the mother to the rat fetus near term: effects on brain 3, 5, 3'-triiodothyronine deficiency. Endocrinology 1988;122:1521-31.

41 Vries de LS, Heckmatt JZ, Burrin JM, et al. Low serum thyroxine concentrations and neural maturation in preterm thyroxine concentrations and neural matura
infants. Arch Dis Child 1986;61:862-6.

42 Larsen PR. Maternal thyroxine and congenital hypothyroidism. N Engl f Med 1989;321:44-6.

43 Lucas A, Rennie J, Baker BA, et al. Low plasma triiodothyronine concentrations and outcome in preterm infants Arch Dis Child 1988:63:1201-6.

44 Hadeed AJ, Assay LD, Klein AH, et al. Significance of transient postnatal hypothyroxinemia in premature infant with and without RDS. Pediatrics 1981;68:494-8.

45 Chowdhry P, Scanlon JW, Auerbach R, et al. Results of controlled double-blind study of thyroid replacement in very low-birth-weight premature infants with hypothyroxinemia. Pediatrics 1984;73:301-5. 